\title{
Wide-range genetic connectivity of Coney, Cephalopholis fulva (Epinephelidae), through oceanic islands and continental Brazilian coast
}

\author{
ALLYSON S. DE SOUZA ${ }^{1,5}$, EURICO A. DIAS JÚNIOR ${ }^{1}$, PEDRO M. GALETTI Jr ${ }^{2}$, \\ ERIK G. MACHADO ${ }^{3}$, MAURO PICHORIM ${ }^{4}$ and WAGNER F. MOLINA ${ }^{1}$ \\ ${ }^{1}$ Departamento de Biologia Celular e Genética, Centro de Biociências, \\ Universidade Federal do Rio Grande do Norte, Laboratório de Genética \\ de Recursos Marinhos, Av. Salgado Filho, s/n, 59078-970 Natal, RN, Brasil \\ ${ }^{2}$ Universidade Federal de São Carlos, Departamento de Genética e Evolução, Via Washington \\ Luis, Km 235, Caixa Postal 676, Monjolinho, 13565-905 São Carlos, SP, Brasil \\ ${ }^{3}$ Centro de Investigaciones Marinas, Universidad de La Habana, Calle 16, \\ No. 114 entre 1ra y 3ra, Miramar, Playa, 11300, La Habana, Cuba \\ ${ }^{4}$ Universidade Federal do Rio Grande do Norte, Centro de Biociências, Departamento de Botânica, \\ Ecologia e Zoologia. Campus Universitário, Lagoa Nova, 59072-970 Natal, RN, Brasil \\ ${ }^{5}$ Programa de Pós-Graduação em Ciências Biológicas, Universidade Federal do Rio Grande \\ do Norte, Campus Universitário, 59072-970 Natal, RN, Brasil
}

Manuscript received on October 17, 2013; accepted for publication on May 30, 2014

\begin{abstract}
The Epinephelidae form a group of species of high biological and economical interests. It's phylogeographic patterns are not well known especially the distributed populations in the western region of the Atlantic Ocean. Among the representatives is a small species called Cephalopholis fulva, Coney, which presents a wide geographical distribution, polychromia, hermaphroditism and is quickly becoming a large target for the exploration of commercial fishing. The genetic and historical demography were obtained through the partial sequence analysis of Control Region from six locations on the coastline of Brazil from the northeast coast to the southwest coast, including the oceanic islands of Rocas Atoll and Fernando de Noronha Archipelago. The analyzed samples revealed a high genetic variability and a strong gene flow among the sampled locations. Additionally, the genetic data revealed that population expansions probably occurred due to the changes in the sea levels that occurred during the Pleistocene. The large population connectivity found in Coney constitutes relevant conditions for their biological conservation.
\end{abstract}

Key words: d-loop, glaciation, mtDNA, panmixia, phylogeography.

\section{INTRODUCTION}

Some species of the Epinephelidae family show peculiar biological characteristics which make them particularly vulnerable to climate changes,

Correspondence to: Allyson Santos de Souza

E-mail: souzaas@yahoo.com.br fishing and environmental degradation, such as high longevity, late sexual maturation, hermaphroditism, reproductive aggregation and need of nurseries in estuarine regions (Coleman 1999). In fact, around $40 \%$ of this family's species are considered under some level of anthropogenic threat (Morris 2000). 
Genetic population studies are scarce for Epinephelidae, despite the family's increasing commercial exploitation (Rivera et al. 2004, Zatcoff et al. 2004, Maggio et al. 2006, Silva-Oliveira et al. 2008). The Epinephelidae family consists of around 160 species distributed in 15 genders (Nelson 2006). This group has representatives of different sizes. For example, the Black grouper, Mycteroperca bonaci Poey, 1860 and the Goliath grouper, Epinephelus itajara Lichtenstein, 1822, which is considered endangered in Brazil (MMA 2004), and smaller species like the Coney, Cephalopholis fulva Linnaeus, 1758.

The biological characteristics of the Coney such as their small size, abundance and broad geographic distribution through Atlantic's Western coast makes this species particularly indicated for phylogeographic analysis. In fact, its geographic distribution extends from the Bermudas and South Carolina (USA), to the Southeast of Brazil, including the oceanic islands in Rocas Atoll, and Fernando de Noronha Archipelago (Heemstra and Randall 1993, Freitas et al. 2003, Sazima et al. 2005) and Trindade and Martim Vaz (Gasparini and Floeter 2001). Polychromatism is a characteristic of this species, not entirely known in all its extension, although it has indications of possible adaptive value, related to the aggressive mimicry of some colors (Sazima et al. 2005).

Some reproductive aspects of marine fishes interfere with the genetic diversity pattern; among them are the sex-determining mechanisms. Like many other Epinephelidae, Coney is a protogynous hermaphrodite, in which the female reaches sexual maturity at $16 \mathrm{~cm}$ and begins their sexual reversion into a male when they reach approximately $20 \mathrm{~cm}$, starting to exhibit territoriality and harem formation (Heemstra and Randall 1993, Coelho 2001, Araújo and Martins 2006). According to the evolutionary point of view, hermaphroditism can be an advantage, in relation to gonochorism, among other aspects, when presented in small populations with great fluctuations between sexes (Borgia and Blick 1981).
DespiteConey notbeing considered an endangered species, its fishing is important in the Caribbean (Trott 2006), and seems to have continually increased due to a displacement of fishing pressure on smaller size species, having in mind the decrease of populations of large fish and the most commercially valued fish (IUCN 2010). In fact, the Coney capture volume has increased since the beginning of the 1990's (Martins et al. 2005). Between the years of 1996 and 2000, the Coney represented $2.4 \%$ of the total fishing production in the Northeast of Brazil (Frédou et al. 2006). With an average of 1,116 tons/year, the Coney represented the most abundant species of collected samples in the Central coast of Brazil (Klippel et al. 2005, Martins et al. 2007). As a result of this exploitation, in some areas the effects of fishing were detected through the abundance and space distribution of the individuals in relation to the depth (Coelho 2001).

Signs of overexploitation of C. fulva, as well as its extensive geographical distribution in the Atlantic Ocean and the presence of many color morphs, make studies that identify its phylogeographic aspects and genetic variability levels particularly favorable. This data will provide a comparative base to establish future interpopulational surveys on this species. Here we present genetic data obtained from partial sequences from the D-loop mitochondrial region from samples collected in a broad ocean strip of the Brazilian coast, covering continental and insular coast environments. The elevated genetic diversity and absence of structuring along all of the sampled areas suggests the existence of a single panmictic population along the Brazilian coast.

\section{MATERIALS AND METHODS}

\section{SPECIMENS ColLeCTiON}

At the conclusion of this research there was no Animal Ethics Committee at the research institute where this study was conducted. Thus, this study was carried out in accordance with Brazilian law regarding the use of laboratory animals 
(Law no. 11.794/2008) and supported by the Brazilian Institute of Environment and Renewable Natural Resources (IBAMA, Processes Numbers 556793/2009-9 and 02001.001902/06-82). The authors underscore that the specimens were sacrificed under complete anesthesia, and all efforts were made to minimize suffering.

A total of 204 specimens of Coney showing different color morphs (Fig. 1A-D) were used in the genetic analysis. The samples were caught in the year 2009, by using line and hook or baited traps, in the ocean islands of Fernando de Noronha
Archipelago and Rocas Atoll, and also the coastal regions of the Northeast and Southeast of Brazilian coasts, most precisely in the coast of the states of Ceará (CE), Rio Grande do Norte (RN), Bahia (BA) and Espírito Santo (ES) (Fig. 1) (Table I). The most extreme collection points covered approximately $2,100 \mathrm{~km}$ of distance. The samples were taxonomically identified according to Heemstra and Randall (1993). Fragments of hepatic tissue and/or fin tissue were conditioned in micro tubes $(1.5 \mathrm{ml})$ with ethylic alcohol and methyl alcohol $(1: 1)$ and stored in temperature of $-20^{\circ} \mathrm{C}$.

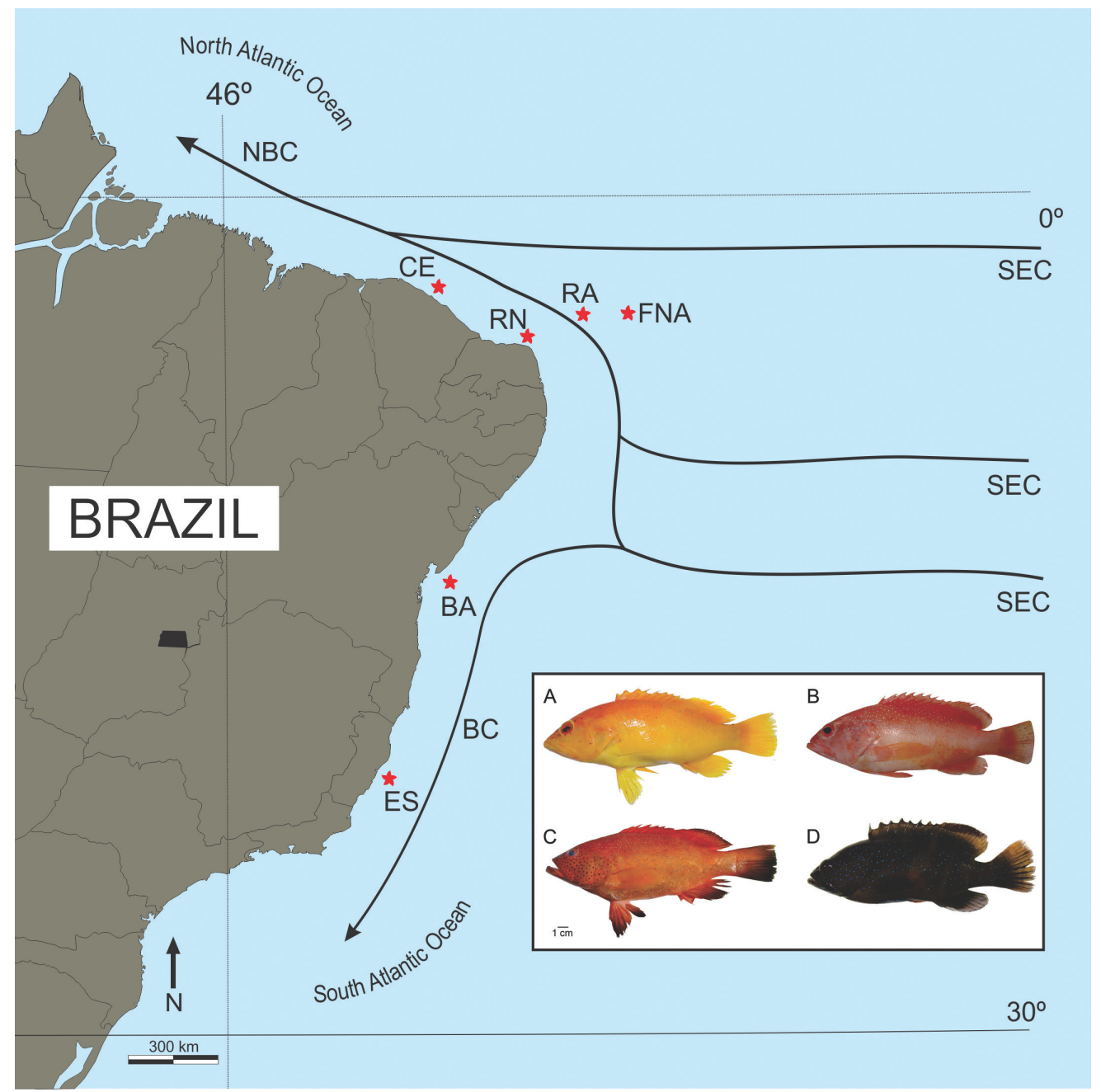

Figure 1 - The Cephalopholis fulva sampling locations are indicated with red stars. Coastal areas: Ceará (CE), Rio Grande do Norte (RN), Bahia (BA) and Espírito Santo (ES). Insular regions: Rocas Atoll (RA) and Fernando de Noronha Archipelago (FNA); SEC = South Equatorial Current, BC = Brazil Current, NBC $=$ North Brazil Current. In detail some color morphs found in Coney (a-d). Photos by Allyson S. Souza. 
TABLE I

Collection points and analyzed samples of coney through the coast of Brazil.

\begin{tabular}{cccc}
\hline Sampled geographical localities & Abbreviation & Geographic Coordinates & n \\
\hline Ceará state & CE & $03^{\circ} 42^{\prime} \mathrm{S}-38^{\circ} 30^{\prime} \mathrm{W}$ & 37 \\
Rio Grande do Norte state & RN & $05^{\circ} 16^{\prime} \mathrm{S}-35^{\circ} 22^{\prime} \mathrm{W}$ & 42 \\
Bahia state & BA & $13^{\circ} 00^{\prime} \mathrm{S}-38^{\circ} 29^{\prime} \mathrm{W}$ & 48 \\
Espírito Santo state & ES & $20^{\circ} 20^{\prime} \mathrm{S}-40^{\circ} 14^{\prime} \mathrm{W}$ & 30 \\
Rocas Atoll & RA & $03^{\circ} 51^{\prime} \mathrm{S}-33^{\circ} 49^{\prime} \mathrm{W}$ & 11 \\
Fernando de Noronha Archipelago & FNA & $03^{\circ} 50^{\prime} \mathrm{S}-32^{\circ} 24^{\prime} \mathrm{W}$ & 36 \\
\hline Total & & & $\mathbf{2 0 4}$ \\
\hline
\end{tabular}

$\mathrm{n}=$ Amostral number.

\section{EXTRACTION, AMPLIFICATION AND DNA SEQUENCING}

The total DNA extraction was performed according to Sambrook et al. (1989). The hypervariable region 1 (HVR=1) of control region (D-loop) of mtDNA was amplified using primers CR-A and CR-E described by Lee et al. (1995). Each reaction contained $4 \mu \mathrm{l}$ of dNTP (1.25 mM), $2.5 \mu$ l of tampon (10x), $1 \mu$ of $\mathrm{MgCl}_{2}(50 \mathrm{mM}), 2.0 \mu \mathrm{l}$ of each primer $(10 \mathrm{pmol} / \mu \mathrm{l})$, 1-1.5 $\mu$ l of total DNA, $0.3 \mu$ of Taq DNA Polimerase $(5 \mathrm{U} / \mu \mathrm{l})$ (Invitrogen, USA) and water Milli-Q for a final volume of reaction of $25 \mu \mathrm{l}$. The used cycling conditions consisted of initial denaturation at $94^{\circ} \mathrm{C}$ for 2 minutes; 30 denaturation cycles at $94^{\circ} \mathrm{C}$ for 45 seconds, hybridization at $52^{\circ} \mathrm{C}$ for 45 seconds, extension at $72^{\circ} \mathrm{C}$ for 1 minute; and final extension at $72^{\circ} \mathrm{C}$ for 2 minutes. The PCR products $(5 \mu \mathrm{l})$ were purified with enzymes exonuclease I (3.3 U/reaction) and shrimp's alkaline phosphatase (0.66 U/reaction) (GE Healthcare), in thermal cycler, submitting the mix to a cycle of $30 \mathrm{~min}$ in $37^{\circ} \mathrm{C}$ and $15 \mathrm{~min}$ in $80^{\circ} \mathrm{C}$. The samples were sequenced in EMBRAPA (Brazilian Company of Agricultural Development) Sequencing Platform through the automatic DNA sequencer ABI Prism 3700 (Applied Biosystems).

mtDNA ANALYSIS

The obtained electropherograms were checked using Bioedit (Hall 1999) and an automatic multiple alignment was performed in the Clustal-X application (Thompson et al. 1997).
The saturation between transitions and transversions in the sequences was checked by the software DAMBE (Xia and Xie 2001). The software jModelTest 2.1.4 (Guindon and Gascuel 2003, Darriba et al. 2012) was used to select the best-fit model of nucleotide substitution. The genetic relationships among samples were evaluated through neighbor-joining method using MEGA5 (Tamura et al. 2011). The significance of the groupings in all generated trees was estimated using bootstrap analysis, based on 1,000 pseudo-replicates.

A haplotype network was set up using the median vector method available in the Network 4.5 program (Bandelt et al. 1999).

The levels of genetic diversity, population structuring, through the estimative of $F_{\mathrm{ST}}$ (Wright 1978), Mantel test (Mantel 1967) and AMOVA (Excoffier et al. 1992) were obtained by Arlequin 3.5 (Excoffier and Lischer 2010). The historical demography was estimated by statistic $F s$ (Fu 1997) and $D$ (Tajima 1989). Complementary to these, the population expansion condition was investigated through analysis of frequencies of the pair-to-pair differences (mismatch distribution), based on three parameters, $\theta_{0}, \theta_{1}$ (frequencies of the pair-to-pair differences between the sequences, before and after the population expansion) and $\tau$ (time of expansion expressed in mutational time unities) (Rogers and Harpending 1992, Rogers 1995). These estimates were obtained using Arlequin 3.5 (Excoffier and 
Lischer 2010). Values of $\tau$ were transformed in real time, since the expansion estimate time, from $u=$ $\mu m t$, where $u$ is the mutational rate by segment of mtDNA, $\mu$ is the mutational rate estimated for the analyzed segment; $m t$ is the amount of the analyzed nucleotide bases. Subsequently, $\tau=2 u t$, where $t$ is the estimated time of expansion occurrence since then. The generation time adopted for the species Coney was one year (Heemstra and Handall 1993, Araújo and Martins 2006, 2009). The mutation rates ( $\mu$ ) adopted for the HVR-1 control region was 8.24 x $10^{-8}$ and $9.30 \times 10^{-8}$ (Domingues et al. 2005). In addition, the raggedness index (Harpending 1994) and the sum of the squared deviations (SSD) between observed and expected mismatch distribution were calculated to validate the estimated expansion model (Schneider and Excoffier 1999).

\section{RESULTS}

\section{SEQUENCE ANALYSIS}

A total of 388 bp of HVR-1 sequence was resolved on 204 specimens (Genbank accession numbers of haplotypes: KC831794 - KC831953) from six geographical localities revealing 94 parsimony informative sites and 153 nucleotide substitutions (23 transversions and 130 transitions). The plot of transition/transversion vs. genetic distance did not indicate the presence of saturation (Fig. 2). The JC Model (Jukes and Cantor 1969) was selected as the best-fit model of nucleotide substitution for the sequences. The content of $\mathrm{A} / \mathrm{T}$ was clearly higher (69.3\%) than $\mathrm{G} / \mathrm{C}(\mathrm{G}=11.46 \%, \mathrm{C}=19.28 \%, \mathrm{~T}=30.14 \%$ e $\mathrm{A}=39.18 \%$ ). The haplotype diversity $(h)$ and nucleotide diversity $(\pi)$ were high and very similar among geographical localities, varying respectively from 0.977 to 0.998 and 0.022 to 0.024 (Table II). These high values of diversity were reflected both in the neighbor-joining analysis, which revealed a large polyatomic tree (there were no significant clusters of samples corresponding to sampling localities; Fig. 3) and in the haplotype analysis, which revealed a star-shaped haplotype network with numerous connections between the median vectors (red circles, Fig. 4), suggesting the existence of a single panmictic population of Coney in Brazilian waters. Furthermore, no genetic differentiation was found among the different color morphs found in Coney.

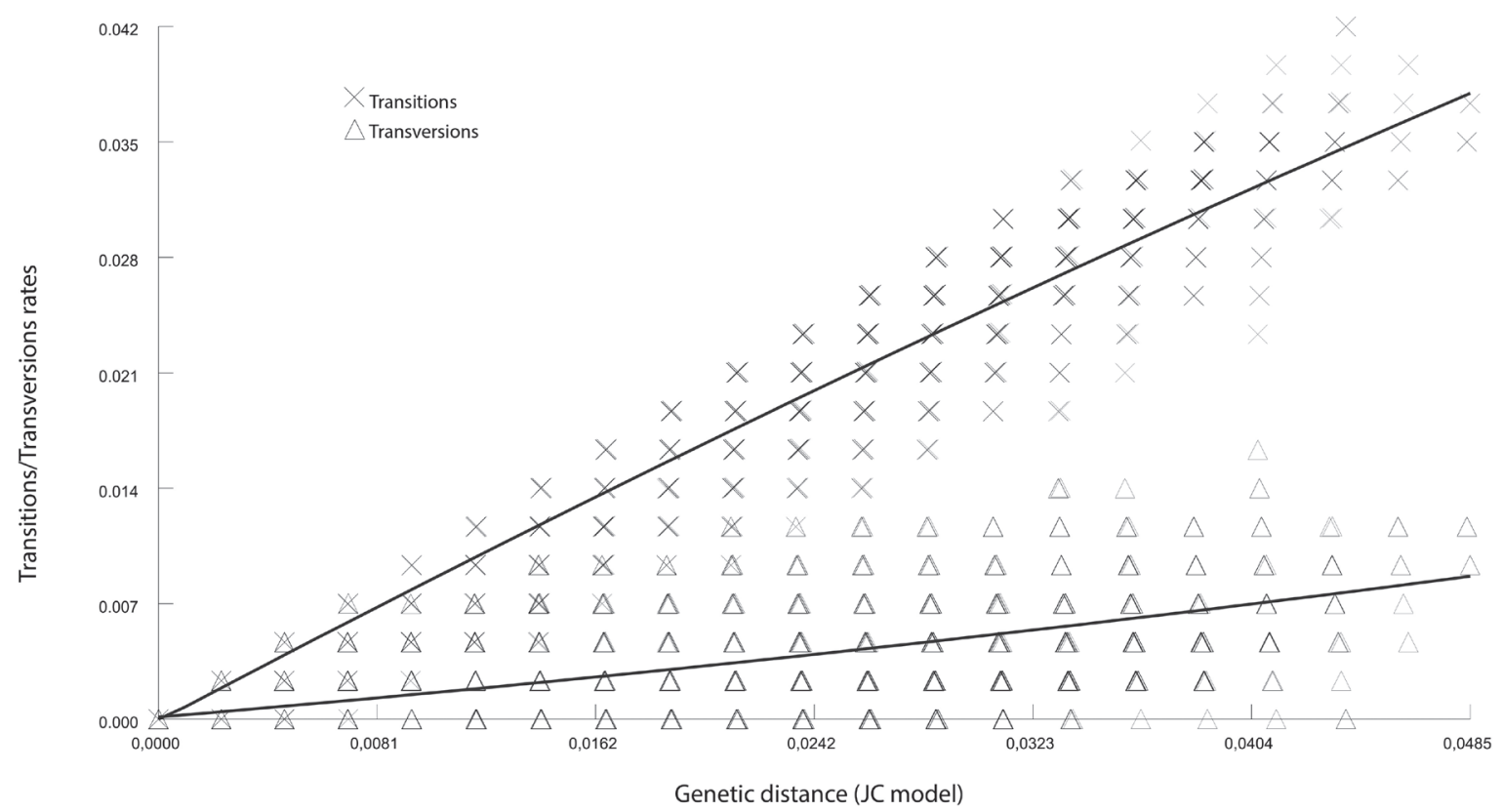

Figure 2 - Plot of transition/transversion rates vs. genetic distance of the HVR-1 sequences of C. fulva. 
TABLE II

Indexes of genetic diversity among geographic samples of coney.

\begin{tabular}{ccccc}
\hline Geographical localities & $\boldsymbol{N}$ & $\mathbf{H}$ & $\boldsymbol{h} \pm \mathbf{s d}$ & $\boldsymbol{\pi} \pm \mathbf{s d}$ \\
\hline Ceará state (CE) & 37 & 36 & $0.998 \pm 0.006$ & $0.023 \pm 0.012$ \\
Rio Grande do Norte state (RN) & 42 & 38 & $0.994 \pm 0.007$ & $0.022 \pm 0.011$ \\
Bahia state (BA) & 48 & 46 & $0.997 \pm 0.005$ & $0.023 \pm 0.012$ \\
Espírito Santo state (ES) & 30 & 22 & $0.977 \pm 0.014$ & $0.024 \pm 0.013$ \\
Rocas Atoll (RA) & 11 & 10 & $0.981 \pm 0.046$ & $0.024 \pm 0.013$ \\
Fernando de Noronha Archipelago (FNA) & 36 & 34 & $0.996 \pm 0.007$ & $0.022 \pm 0.011$ \\
Insular populations (RA, FNA) & 47 & 43 & $0.995 \pm 0.005$ & $0.023 \pm 0.012$ \\
Coastal populations (CE, RN, BA, ES) & 157 & 134 & $0.997 \pm 0.001$ & $0.023 \pm 0.011$ \\
All populations (CE, RN, RA, FNA, BA, ES) & 204 & 173 & $0.997 \pm 0.000$ & $0.023 \pm 0.011$ \\
\hline
\end{tabular}

$N=$ number of individuals; $\mathrm{H}=$ number of haplotypes; $h$ = haplotype diversity; $\pi=$ nucleotide diversity; $\mathrm{sd}=$ standard deviation.

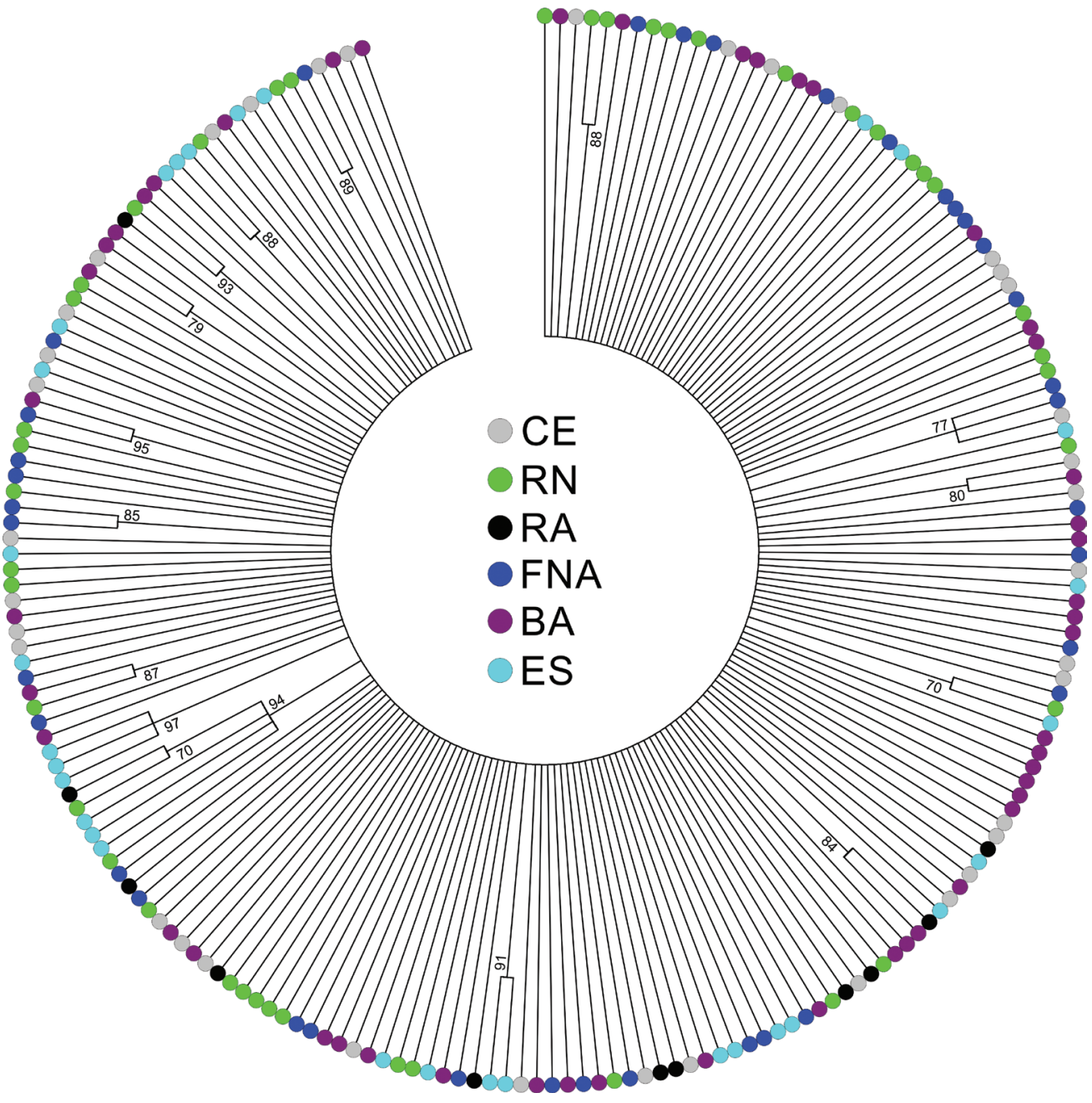

Figure 3 - Neighbor-joining tree constructed using Jukes and Cantor distances and inferred from 204 samples of Coney. Each color represents where each sample was collected. $\mathrm{CE}=$ Ceará, $\mathrm{RN}=$ Rio Grande do Norte, $\mathrm{RA}=$ Rocas Atoll, FNA = Fernando de Noronha Archipelago, BA = Bahia, ES = Espírito Santo. Bootstrap values greater than 70 are shown in the branches. 


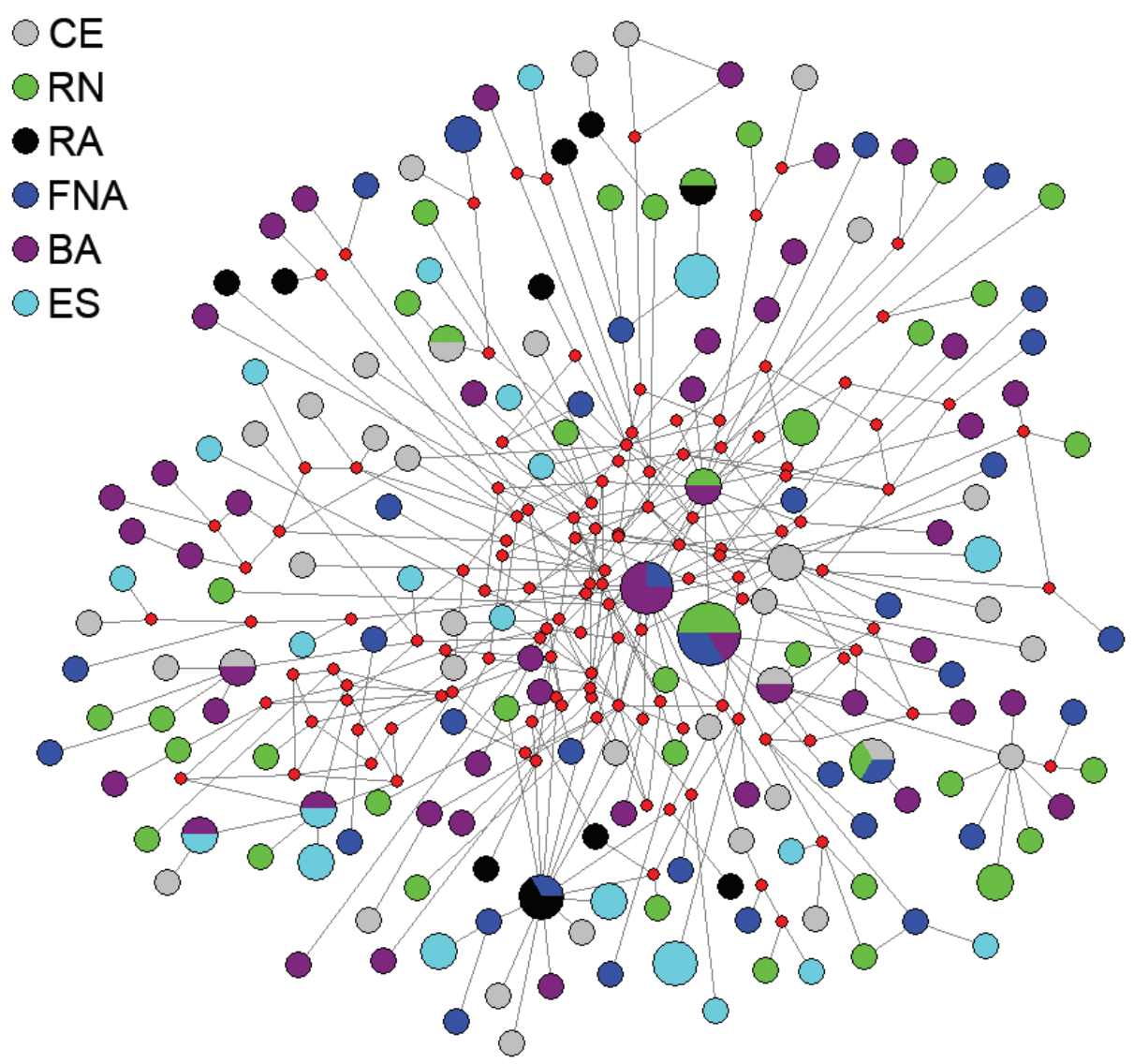

Figure 4 - Haplotype network based on HVR-1 sequences of Coney. The size of the circles are proportional to the frequency of haplotypes. Each color represents where each sample was collected. CE = Ceará, RN = Rio Grande do Norte, RA = Rocas Atoll, FNA $=$ Fernando de Noronha Archipelago, $\mathrm{BA}=$ Bahia, $\mathrm{ES}=$ Espírito Santo.

TABLE III

$F_{S T}$ estimatives between geographical populations based on HVR-1 of coney.

\begin{tabular}{ccccccc}
\hline Areas & CE & RN & RA & FNA & BA & ES \\
\hline CE & - & $0.761 \pm 0.0057$ & $0.183 \pm 0.0034$ & $0.650 \pm 0.0045$ & $0.601 \pm 0.0042$ & $0.206 \pm 0.0043$ \\
RN & -0.006 & - & $0.659 \pm 0.0019$ & $0.659 \pm 0.0042$ & $0.540 \pm 0.0048$ & $0.052 \pm 0.0016$ \\
RA & 0.015 & 0.031 & - & $0.059 \pm 0.0022$ & $0.047 \pm 0.0018$ & $0.105 \pm 0.0035$ \\
FNA & -0.004 & -0.004 & 0.028 & - & $0.279 \pm 0.0042$ & $0.029 \pm 0.0017$ \\
BA & -0.003 & -0.001 & $0.035^{*}$ & 0.003 & - & $0.033 \pm 0.0017$ \\
ES & 0.007 & 0.019 & 0.031 & $0.025^{*}$ & $0.020^{*}$ & - \\
\hline
\end{tabular}

Upper diagonal $=p$ values \pm confidence interval; below diagonal $=$ Fst values; $* p<0.05$.

\section{POPULATION STRUCTURING}

The pairwise population comparison by $F_{S T}$ (Wright 1978) showed, in most cases, negative or not significant values. Just three situations with significant $F_{S T}$ were found, which were between Bahia and Espírito Santo $\left(F_{S T}=0.020\right)$, Fernando de Noronha
Archipelago and Espírito Santo $\left(F_{S T}=0.025\right)$ and between Rocas Atoll and Bahia $\left(F_{S T}=0.035\right)$ (Table III). The Mantel test found no association between the $F_{S T}$ values and geographic distances $(\mathrm{p}>0.05)$.

AMOVA analyses using different population groupings indicate that the higher variation 
percentage happens within populations $(97.27 \%$ 99.54\%) and no significant differentiation between the groupings coast-to-coast, coast-to-island or island-to-island (Table IV).

\section{NEUTRALITY AND DEMOGRAPHIC HISTORY}

The neutrality tests showed negative values for $D$ and $F s$ for all sampled geographical localities and groupings (Table V), which indicates the non-neutral nature of the Coney's HVR-1, and supports the hypothesis of demographic expansion. The mismatch distribution revealed in a general unimodal pattern, especially for the groupings "Insular populations", "Coastal populations" and "All populations", supporting a model of sudden expansion (Fig. 5). In addition to these tests, raggedness index and SSD (Harpending 1994) also supports the idea that Brazilian Coney population is undergoing expansion (Table $\mathrm{V}$ ).

TABLE IV

Hierarchical analysis of molecular variance (AMOVA) based on HVR-1 of coney.

\begin{tabular}{|c|c|c|c|c|}
\hline Comparisons & Source of variation & $\begin{array}{l}\text { Percentage of } \\
\text { variation }\end{array}$ & $\phi$ statistic & p value \\
\hline \multicolumn{5}{|l|}{ All localities } \\
\hline \multirow{2}{*}{ (CE, RN, RA, FNA, BA, ES) } & Among populations & 0.65 & $\phi s t=0.006$ & 0.057 \\
\hline & Within populations & 99.35 & - & - \\
\hline \multirow{4}{*}{$\begin{array}{c}\text { Insular vs. coastal localities } \\
((\mathrm{RA}, \mathrm{FNA}) \times(\mathrm{CE}, \mathrm{RN}, \mathrm{BA}, \mathrm{ES}))\end{array}$} & & & & \\
\hline & Among groups & -0.21 & $\phi c t=-0.002$ & 0.415 \\
\hline & Among populations within groups & 0.74 & $\phi s c=0.007$ & $0.044^{*}$ \\
\hline & Within populations & 99.47 & $\phi s t=0.005$ & $0.046^{*}$ \\
\hline \multicolumn{5}{|l|}{ Insular localities } \\
\hline \multirow[t]{2}{*}{ (RA, FNA) } & Among populations & 2.73 & $\phi s t=0.027$ & 0.056 \\
\hline & Within populations & 97.27 & - & - \\
\hline \multicolumn{5}{|l|}{ Coastal localities } \\
\hline \multirow{3}{*}{$(\mathrm{CE}, \mathrm{RN}, \mathrm{BA}, \mathrm{ES})$} & Among populations & 0.46 & $\phi s t=0.004$ & 0.111 \\
\hline & Within populations & 99.54 & - & - \\
\hline & Within populations & 97.27 & - & - \\
\hline
\end{tabular}

*Significant at the 0.05 level.

TABLE V

Neutrality and geographic expansion indexes of coney geographic samples.

\begin{tabular}{|c|c|c|c|c|c|c|c|c|}
\hline $\begin{array}{c}\text { Geographical } \\
\text { localities }\end{array}$ & D & Fs & $\Theta_{0}$ & $\Theta_{1}$ & Rag. (p) & $\operatorname{SSD}(p)$ & $\tau$ & $\begin{array}{c}\text { Time } \\
\left(10^{3} \text { years ago }\right)\end{array}$ \\
\hline $\mathrm{CE}$ & $-1.70 * *$ & $-24.78 * *$ & 0.010 & 234.843 & $0.006(0.72)$ & $0.001(0.57)$ & 9.4 & $135-130$ \\
\hline $\mathrm{RN}$ & $-1.77 * *$ & $-24.78 * *$ & 0.012 & 78.681 & $0.006(0.71)$ & $0.002(0.52)$ & 9.6 & $150-133$ \\
\hline RA & -1.00 & -2.40 & 0.008 & 108.046 & $0.036(0.52)$ & $0.012(0.63)$ & 10.2 & $159-141$ \\
\hline FNA & $-1.66^{* *}$ & $-24.80 * *$ & 0.000 & 255.000 & $0.006(0.98)$ & $0.037(0.00 * *)$ & 5.7 & $89-78$ \\
\hline BA & $-1.69 * *$ & $-24.75^{* *}$ & 0.008 & 116.445 & $0.005(0.82)$ & $0.000(0.84)$ & 9.5 & $148-131$ \\
\hline ES & -1.04 & $-6.58 * *$ & 0.000 & 9999.00 & $0.015(0.12)$ & $0.007(0.09)$ & 10.2 & $159-141$ \\
\hline $\begin{array}{l}\text { Insular localities } \\
\text { (RA, FNA) }\end{array}$ & $-1.79 * *$ & $-24.76^{* *}$ & 2.376 & 122.031 & $0.004(0.82)$ & $0.000(0.80)$ & 7.1 & $111-98$ \\
\hline $\begin{array}{l}\text { Coastal localities } \\
\text { (CE, RN, BA, ES) }\end{array}$ & $-1.86^{* *}$ & $-24.40 * *$ & 0.021 & 224.687 & $0.005(0.52)$ & $0.000(0.25)$ & 9.6 & $148-131$ \\
\hline $\begin{array}{c}\text { All localities } \\
\text { (CE, RN, RA, } \\
\text { FNA, BA, ES) }\end{array}$ & $-1.92 * *$ & $-24.30 * *$ & 0.031 & 127.421 & $0.004(0.72)$ & $0.000(0.60)$ & 9.5 & $135-130$ \\
\hline
\end{tabular}

$D=$ Tajima's $D ; F s=$ Fu's Fs; $\Theta_{0}$ e $\Theta_{1}=$ Mutation parameters before and after expansion, respectively; Rag. $=$ Raggedness index; SSD = Sum of the squared deviations; $\tau=$ Mode of the mismatch distribuition; ${ }^{*} p<0.05 ; * * p<0.01$. 

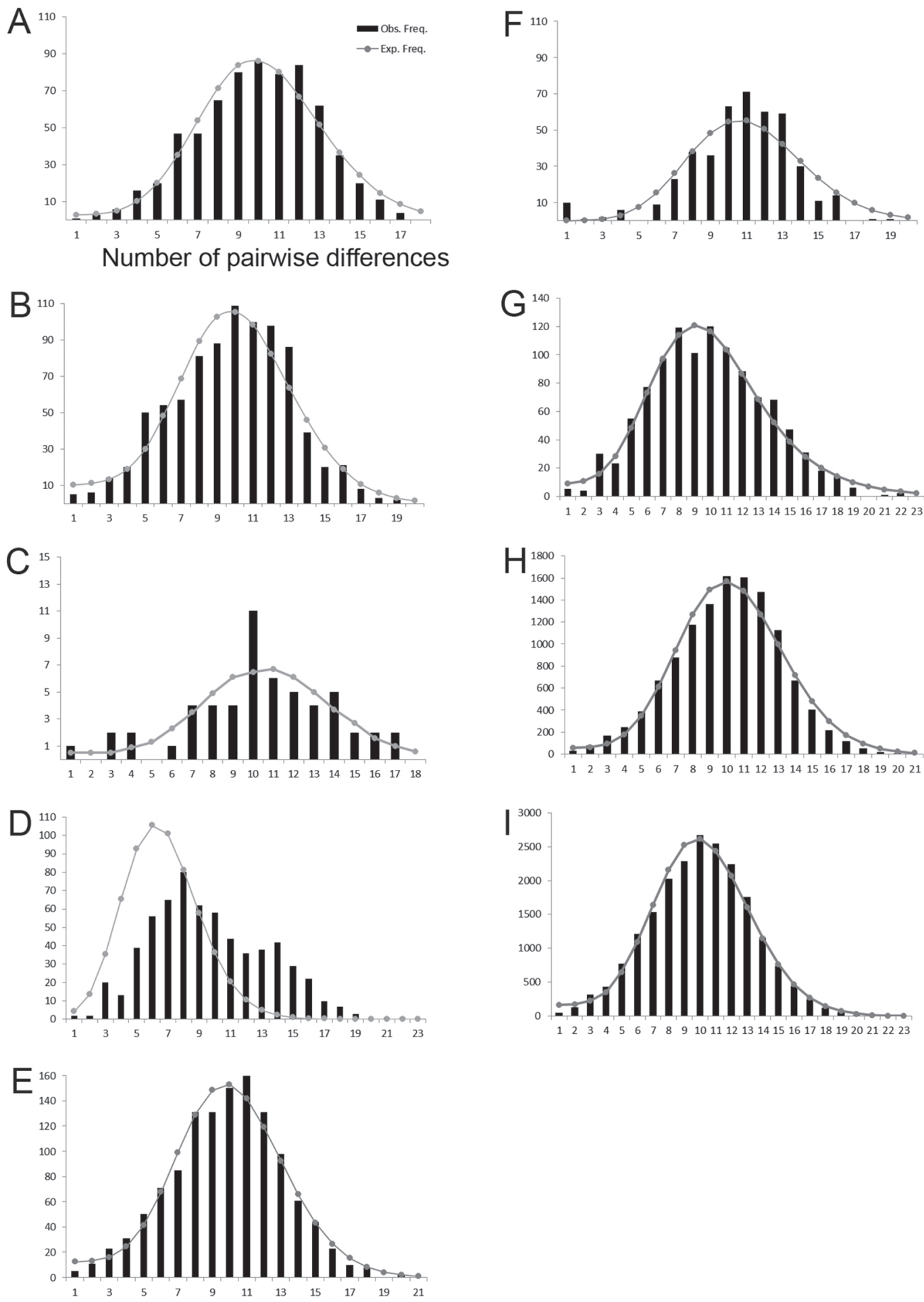

Figure 5 - Pairwise mismatch distribution for HVR-1 of Coney. A = Ceará (CE), B = Rio Grande do Norte $(\mathrm{RN}), \mathrm{C}=\mathrm{Rocas}$ Atoll (RA), D = Fernando de Noronha Archipelago (FNA), E = Bahia (BA), F = Espírito Santo (ES), G = Insular populations (RA, FNA), $\mathrm{H}=$ Coastal populations (CE, RN, BA, ES) and I = All populations (CE, RN, RA, FNA, BA, ES). 
The estimate $\tau$ values indicate that demographic expansions in this species happened between 98 and 111 thousand years ago in insular populations (Rocas Atoll and Fernando de Noronha Archipelago) and between 131 and 148 thousand years ago in coastal populations $(\mathrm{CE}, \mathrm{RN}, \mathrm{BA}$, and ES). Considering a panmixia framework and analyzing all sampled populations as one, the expansion would have happened between 130 - 135 thousand years ago (Table V).

\section{DISCUSSION}

\section{Genetic VARIABILITY AND STRUCTURE OF CONEY}

POPULATION

The control region mtDNA of the geographic samples of Coney show high values of haplotype diversity (0.977- 0.998) and nucleotide diversity $(2.2 \%-2.4 \%)$, when compared with another Atlantic grouper, Epinephelus itajara (Silva-Oliveira et al. 2008). Silva-Oliveira et al. (2008) have analyzed populations of E. itajara in the Northern Brazilian coast and found values of haplotype and nucleotide diversity considerably lower, varying from 0.86 0.53 and $0.5 \%-0.1 \%$, respectively. E. itajara is a critically endangered species, and according to the authors, its low diversity values were related to high fishing pressure and loss of habitat.

The low $F_{S T}$ values suggest extensive gene flow in almost all sampled regions, besides collected individuals located more to the South (ES) showed little genetic differentiation with those in Fernando de Noronha Archipelago (FNA) and Bahia (BA), more to the North. Likewise, the sample of BA also showed a small differentiation with samples from Rocas Atoll (RA). Curiously, the population of RA shows more similarity with the population of ES, farther south. This condition could suggest recent restrictions between these places; however, a biased sample can not be discarded. Incongruities between genetic patterns and geographical distribution along the Brazilian coast were also observed between populations of the Lutjanidae Ocyurus chrysurus (Vasconcellos et al. 2008).

The estimate of $F_{S T}$, haplotype network and neighbor-joining analysis can not indicate genetic differentiation along the coast and ocean islands suggesting a genetic connectivity among the sites. In fact, the AMOVA analysis indicated that the highest genetic variation happens within populations. A low differentiation, next to the critical significance limit was shown between populations within groups ((RA, FNA) x (CE, RN, $\mathrm{BA}, \mathrm{ES}))\left(\phi_{\mathrm{SC}}=0.007, p=0.041\right)$. However, when analyzing insular locations (RA, FNA) versus coastal locations (CE, RN, BA, ES), the differences found do not reveal real groupings ( $p=0.057$ and $p=0.126$, respectively). Furthermore, the presence of different color patterns found in Coney seems to be related to environmental or biological factors, because there is no genetic differentiation among the sampled color morphs. However, further analysis using nuclear genes may be used to confirm this condition.

The genetic homogeneity observed in Coney appears very different from other representatives of Epinephilinae, in which a pronounced genetic structuring has been identified in some grouper species such as Epinephelus akaara $\left(F_{S T} \leq 0.379\right.$; $p<0.001$ ) (Chen et al. 2008) and Epinephelus labriformis $\left(F_{S T} \leq 0.661 ; p=0.001\right)$ (Craig et al. 2006). Although other evidence is needed, the low level of genetic differentiation among the sampled locations could be related to the absence of dependence from estuarine regions in any life stage of the Coney, the adding of continuity of rocky substrates along the Brazilian coast and a directional regime of North and South currents.

HISTORICAL DEMOGRAPHY OF CONEY IN THE BRAZILIAN COAST

The glaciations of Pleistocene, have often been appointed as being relevant events for the establishment of phylogeographic and population 
patterns currently shown by marine fish (Domingues et al. 2005, 2006, 2007, Santos et al. 2006, Craig et al. 2006, Zhang et al. 2006, He et al. 2010, Mobley et al. 2010, Viñas et al. 2010). In this sense, indicative indexes of the samples' demographic past for each region were used, not only individually but also through geomorphological criteria for samples jointly placed in coastal and insular regions. Both neutrality tests $F S$ and $D$, showed negative and highly significant results, like mismatch distribution which appears unimodal, used in insular and coast clusters which appeared compatible with the populations that suffered expansion (Slatkin and Hudson 1991, Rogers and Harpending 1992, Ray et al. 2003, Excoffier 2004).

Dating by oxygen isotopes in two marine terraces of RN's coast indicated that the Atlantic's level in this region reached $8 \pm 2 \mathrm{~m}$ above the current sea level around $123.5 \pm 5.7$ thousand years ago (Fig. 6), period of the Pleistocene's penultimate sea transgression (Barreto et al. 2002). Similar ocean elevation levels were determined for marine terraces located in BA's coast (Bernat et al. 1983). This period corresponds to approximately the same period of the last population expansion of Coney in areas of the continental platform.

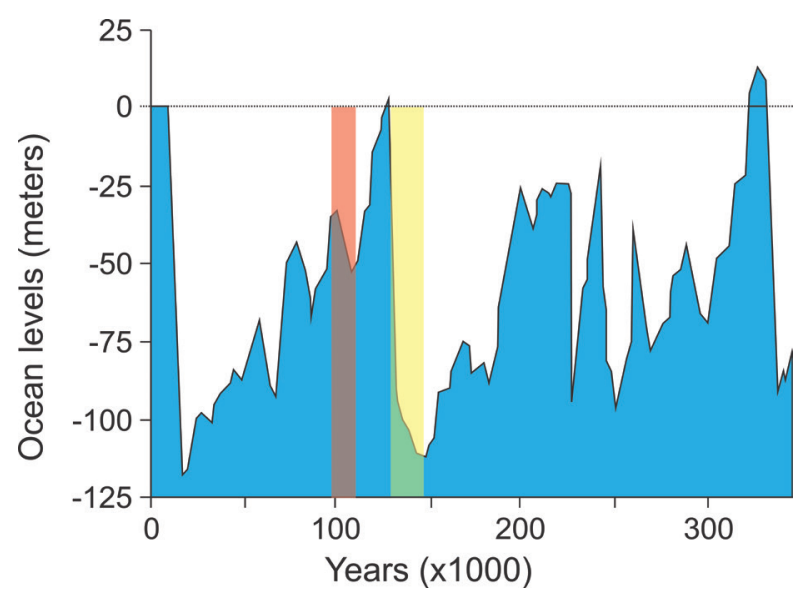

Figure 6 - Variations of Atlantic Ocean's level and periods of population expansion of Coney in Brazilian coast (between 148,000 and 131,000 years; in yellow) and islands (between 111,000 and 98,000 years; in red). Modified from Barreto et al. 2002.
Distinct events seem to have influenced the asynchronic population expansion in insular and coastal clusters. The demographic expansion in coast cluster (CE, RN, BA, ES) occurred with a smaller number of individuals $\left(\theta_{0}=0.021\right)$ than in insular regions $\left(\theta_{0}=2.376\right)$. In fact, in coastal regions, the data shows a demographic expansion of Coney that is coincidental with the penultimate sea transgression which reached its top around $123.5 \pm 5.7$ thousand years ago, when the continental shelf was submerged again, making new habitats available to be taken, consequently causing the population expansion, emphasized in coast populations (see Fig. 7B).

This transgression event (during the Glacial Minimun) of Pleistocene is preceded by the maximum sea regression, occurred around 140 thousand years ago, which in some areas reached up to 100 meters below the current level (Hearty 1998) making practically the whole Brazilian continental shelf emerge. In this occasion the loss of broad natural habitat areas in the Brazilian coast possibly resulted in a deep decrease of population effectives in the Brazilian coast (Fig. 7C), like suggested by the low values of $\theta_{0}$ (Table V). In this period, as the continental shelf was emerged, Coney came to occupy seamounts that were not accessible due to depth, and a narrow area of the continental slope, which the depth has become the limiting factor for the occupation of Coney in the continental slope (Fig. 7C).

More recently, in last glaciation period, in the course of a growing decrease of the Atlantic Ocean's level (Fig. 6), a population expansion involving only contingents of Coney located in insular environments was noticed. Values of $\theta_{0}$ found for insular populations were much higher than those found in coast populations, indicating population expansion from a higher number of Coney individuals than those in the continent.

Coney inhabits areas in depths from 2 to 35 meters (Gasparini and Floeter 2001), although the species have already been registered in 150 meters 


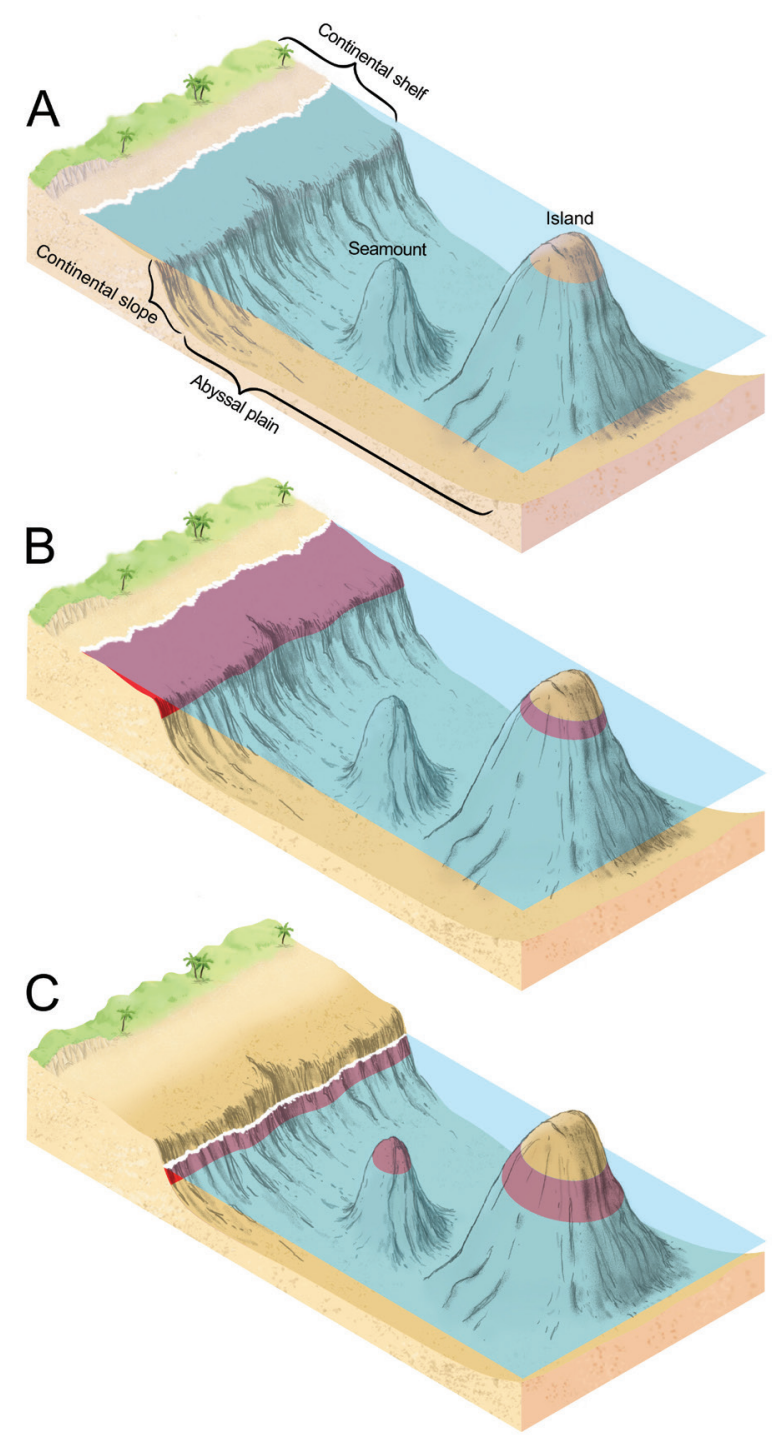

Figure 7 - Illustration representing the occupation areas of Coney along the variations of the sea levels during the Pleistocene; $\mathrm{A}=$ Submarine relief of the Brazilian coast and oceanic islands and the current sea level; Red areas represent the habitat occupied by Coney during periods of transgression (B) and marine regression (C).

of depth (Smith 1997), as represented in Fig. 7. So, its populations seem intensely prone to suffering interference by loss of areas in the continental platform during sea regressions (Fig. 7C). Besides, in general, ocean islands are considered more sensitive environments to environmental effects, they seem to have kept more population effectives during sea regressions, by habitat expansion areas (Fig. 7C), consequently bringing higher environmental stability in relation to coastal areas, which are more shallow.

SYNERGISTIC ACTION OF FACTORS WHICH INTERFERE IN HistoricAl DEMOGRAPHY AND POPULATION CONNECTIVITY

Among the conditions that can be suggested for population expansions in Coney, some environmental characteristics of geologic/geographic nature seem to have contributed to a higher $\theta_{0}$ and asynchrony of the expansion period for insular populations.

The geological conformation and geographic position in which the oceanic islands of Fernando de Noronha Archipelago and Rocas Atoll are located, could have positively contributed to the maintenance of genetic homogeneity. These regions form, equally, conical mounts supported by the oceanic floor around 4,000 meters of depth (as represented in the Fig. 7A), depth much higher than that shown by the continental platform, but also easily impacted by sea regressions. For having conical shape, retractions of sea level could increase the available of rocky areas and consequently the areas of habitats for Coney individuals (Fig. 7C). This condition can explain the fact that the population expansion in Fernando de Noronha Archipelago and Rocas Atoll happened in a period of regression of the Atlantic Ocean's levels.

According to the geographic view, Fernando de Noronha Archipelago and Rocas Atoll are part of an alignment of, at least, six more submarine mounts of volcanic origin, the Fernando de Noronha Range which extends in continent direction. From this range, currently only these two insular regions are immersed (Almeida 2002, Kikuchi 2002), but under a scenario of decrease in the sea level, the insular environments could be wider and shelter more effectives of Coney from other historically immersed areas as the sea mountains (Fig. 7C).

Although evidences are preliminary, the low indexes of structuring of Coney between insular and continent regions or between continent regions can be explained by biological factors of the species and 
geological conditions of the environment in which the species inhabits. This species shows high larval production, with release of 150.000 to 282.000 eggs per female (Heemstra and Randall 1993). Despite the absence of data about the duration of the larval pelagic, in some representatives of the Epinephelidae family, this stage can reach 80 days (Lara et al. 2009), a period which is considered to be long comparing it to other Perciformes. In fact, the broad geographic distribution of Coney (Nelson 2006, Heemstra and Randall 1993), suggests an elevated level of dispersion and colonization of the species.

Associated to these biological characteristics, a system of ocean currents in the Brazilian Atlantic coast (Fig. 1) favors the larval dispersion and the subsequent population homogeneity. The main ocean current present in the Brazilian coast is the South Equatorial Current (SEC), which flows in East/West direction and forks between latitudes 12 and 14, forming the North Brazil Current (NBC) and the Brazil Current (BC). Brazil Current flows parallel to the continental platform, in Northeast/ Southeast direction while North Brazil Current flows in Northeast/North direction (Castro and Miranda 1998, Lumpkin and Garzoli 2005). In the region of Fernando de Noronha's range of mountains, the Atlantic Equatorial Current (AEC), which originates between the North and Northeast coasts of Brazil, flows under and in opposite direction of the South Equatorial Current (Mendes 2006). The action of single currents on a vast geographic area seems to perform an important role in the larval dispersion and genetic homogeneity of Coney.

Despite Coney being an increasing target of fishing for several years, the genetic profile obtained for the species does not show damaging effects coming from overfishing up until the present. Other than this, evidence of genetic connectivity has not been found among continent/ continent, continent/island and island/island areas.
The broad geographic distribution, the small size of sexual maturation and the decrease in competition by capturing bigger size predators can be positively influencing its abundance and maintenance of genetic variability. So, even though Coney in Brazilian coast does not suggest specific handling actions, the genetic data which was obtained, allow monitoring and accessing the conservation status of the species in the future.

\section{ACKNOWLEDGMENTS}

The authors are grateful to Instituto Chico Mendes de Conservação da Biodiversidade for the license to specimens' collection (Proc. 02001.001902/06-82); Dr. José Garcia Jr. for the taxonomic identification of specimens; Daywison Thales Sales Martins for the illustration (Fig. 7); Academia Brasileira de Ciências through the "Programa Aristides Pacheco Leão for the training granted and performed in 2006 by Allyson S. Souza at the Universidade Federal do Pará under the supervision of professors Dr. Horácio Schneider, Dra. Iracilda Sampaio and Dr. Marcelo Vallinoto; They are also grateful to the National Institute of Science and Technology in Marine Sciences (INCT/CNPq) and Conselho Nacional de Desenvolvimento Científico e Tecnológico (CNPq) for the financial support.

\section{RESUMO}

Epinephelidae forma um grupo de espécies de grande interesse biológico e econômico. Seus padrões filogeográficos são pouco conhecidos, principalmente nas populações distribuídas na região oeste do Oceano Atlântico. Entre seus representantes está a pequena espécie Cephalopholis fulva, Coney, a qual apresenta ampla distribuição geográfica, policromia e hermafroditismo, além de estar se tornando um alvo crescente da exploração pesqueira comercial. Os dados genéticos e histórico-demográficos foram obtidos através da análise de sequências parciais da Região Controle de seis localidades do litoral brasileiro, desde 
o Nordeste até o Sudeste do Brasil, incluindo as ilhas oceânicas do Atol das Rocas e do arquipélago Fernando de Noronha. As amostras analisadas revelaram uma alta variabilidade genética e um forte fluxo gênico entre as localidades amostradas. Além disso, os dados genéticos relevaram expansões populacionais provavelmente relacionadas às mudanças no nível do mar ocorridas durante o Pleistoceno. A ampla conectividade populacional presente em Coney constitui uma condição relevante para a sua conservação biológica.

Palavras-chave: d-loop, glaciação, mtDNA, panmixia, filogeografia.

\section{REFERENCES}

AlmeIDA FFM. 2002. Arquipélago de Fernando de Noronha - Registro de monte vulcânico do Atlântico Sul. In: Schobbenhaus C, Campos DA, Queiroz ET, Winge $\mathrm{M}$ and Berbert-Born MLC (Eds), Sítios Geológicos e Paleontológicos do Brasil. $1^{\text {a }}$ ed., Brasília: DNPM/ CPRM - Comissão Brasileira de Sítios Geológicos e Paleobiológicos (SIGEP), p. 361-368.

ARAÚJO JN AND MARTINS AS. 2006. Age and growth of Coney (Cephalopholis fulva), from the central coast of Brazil. J Mar Biol Assoc UK 86: 187-191.

ARAÚJO JN AND MARTINS AS. 2009. Aspects of the population biology of Cephalopholis fulva from the central coast of Brazil. J Appl Ichthyol 25: 328-334.

BANDELT HJ, FORSTER P AND RoHL A. 1999. Median-joining networks for inferring intraspecific phylogenies. Mol Bio Evol 16: 37-48.

Barreto AMF, Bezerra FHR, Suguio K, Tatumi SH, Yee M, PAIVA RP AND Munita CS. 2002. Late Pleistocene marine terrace deposits in northeastern Brazil: sea-level change and tectonic implications. Palaeogeogr Palaeocl 179: 57-69.

BERnAT M, MARTIN L, BITTENCOURT ACSP AND VILAS-BoAS GS. 1983. Datation Io/U du plus haut niveau marin du dernier interglaciaire sur le côte du Brésil. Utilization du $229 \mathrm{Tl}$ comme traceur. Comptes rendus de l'Académie des Sciences, Paris 296: 197-200.

Borgia G AND BLICK J. 1981. Sexual competition and the evolution of hermaphroditism. J Theor Biol 89: 523-532.

CASTRO BM AND Miranda LB. 1998. Physical oceanography of the western Atlantic continental shelf located between $4^{\circ} \mathrm{N}$ and $34{ }^{\circ} \mathrm{S}$. In: Robinson AR and Brink $\mathrm{KH}$ (Eds), The Sea, ideas and observations on progress in the study of the seas, vol. 11, New York: J Wiley \& Sons, p. 209-251.

Chen S, LiU T, Li Z And GaO T. 2008. Genetic population structuring and demographic history of red spotted grouper (Epinephelus akaara) in South and East China Sea. Afr J Biotechnol 7: 3554-3562.
COELHO FN. 2001. Distribuição, abundância e biologia reprodutiva da garoupinha, Cephalopholis fulva (Linnaeus, 1758) (Perciformes, Serranidae, Epinephelinae), na costa central do Brasil. Tese de Mestrado, Universidade Federal Fluminense, Rio de Janeiro, Brasil. (Unpublished).

COLEMAN FC. 1999. Management and Conservation of Temperate Reef Fishes in the Grouper-Snapper Complex of the Southeastern United States. Am Fish Soc Symp 23: 233-242.

Craig MT, Hastings PA, Pondella DJ, Robertson DR AND Rosales-CASIA JA. 2006. Phylogeography of the flag cabrilla Epinephelus labriformis (Serranidae): implications for the biogeography of the Tropical Eastern Pacific and the early stages of speciation in a marine shore fish. J Biogeogr 33: 969-979.

Darriba D, TABoAda GL, Doallo R and Posada D. 2012. jModelTest 2: more models, new heuristics and parallel computing. Nat Methods 9: 772.

DOMINGUES VS, BUCCIARELLI G, ALMADA VC AND BERNARDI G. 2005. Historical colonization and demography of the mediterranean damselfish, Chromis chromis Mol Ecol 14: 4051-4063.

Domingues VS, SANTOS RS, BRito A, Alexandro M AND ALMADA VC. 2007. Mitochondrial and nuclear markers reveal isolation by distance and effects of Pleistocene glaciations in the northeastern Atlantic and Mediterranean populations of the white seabream (Diplodus sargus, L.). J Exp Mar Biol Ecol 346: 102-113.

Domingues VS, SANTOS RS, BRito A AND Almada VC. 2006. Historical population dynamics and demography of the eastern Atlantic pomacentrid Chromis limbata (Valenciennes, 1833). Mol Phylogenet Evol 40: 139-147.

EXCOFFIER L. 2004. Patterns of DNA sequence diversity and genetic structure after a range expansion: Lessons from the infinite-insular model. Mol Ecol 13: 853-864.

EXCOFFIER L AND LISCHER HEL. 2010. Arlequin suite ver 3.5: A new series of programs to perform population genetics analyses under Linux and Windows. Mol Ecol Resour 10: 564-567.

EXCoffier L, SMouse PE AND QuATtro JM. 1992. Analysis of molecular variance inferred from metric distances among DNA haplotypes: application to human mitochondrial DNA restriction data. Genetics 131: 479-491

FrÉDOU T, FERREIRA BP AND LETOURNEUR Y. 2006. A univariate and multivariate study of reef fisheries off northeastern Brazil. Ices J Mar Sci 63: 883-896.

Freitas JEP, ARAÚJO ME AND SOLÉ-CAVA AM. 2003 Estruturação genética das populações de duas espécies de peixes recifais do Atol das Rocas e da costa do Ceará. Trop Oceanogr 31: 193-201.

FU YX. 1997. Statistical tests of neutrality of mutations against population growth, hitchhiking and background selection. Genetics 147: 915-925.

GASPARINI JL AND FlOETER SR. 2001. The shore fishes of Trindade Insular, western South Atlantic. J Nat Hist 35: 1639-1656. 
GUINDON S AND GASCUEL O. 2003. A simple, fast and accurate method to estimate large phylogenies by maximumlikelihood. Syst Biol 52: 696-704.

HALL TA. 1999. BioEdit: a user-friendly biological sequence alignment editor and analysis program for Windows 95/98/NT. Nucl Acids Symp Ser 41: 95-98.

HARPENDING HC. 1994. Signature of ancient population growth in a low-resolution mitochondrial DNA mismatch distribution. Hum Biol 66: 591-600.

He L, Zhang A, Weese D, Zhu C, Jiang C and Qiao Z. 2010. Late Pleistocene population expansion of Scylla paramamosain along the coast of China: A population dynamic response to the Last Interglacial sea level high stand. J Exp Mar Biol Ecol 385: 20-28.

HEARTY PJ. 1998. The geology of Eleuthera Insular, Bahamas: a rosetta stone of Quaternary stratigraphy and sea-level history. Quaternary Sci Rev 17: 333-335.

HEEMSTRA PC AND RANDALL JE. 1993. FAO species catalogue. Vol. 16. Groupers of the world (Family Serranidae, Subfamily Epinephelinae). An annotated and illustrated catalogue of the grouper, rockcod, hind, coral grouper and lyretail species known to date. FAO Fisheries Synopsis. No. 125, vol. 16, Rome, 382 p.

IUCN. 2010. IUCN Red List of Threatened Species. Version 2010.4. <www.iucnredlist.org>. Downloaded on 25 November 2010.

JUKES TH AND CANTOR CR. 1969. Evolution of protein molecules. In: Munro HN (Ed), Mammalian Protein Metabolism, New York: Academic Press, p. 21-132.

KIKUCHI RKP. 2002. Atol das Rocas, Litoral do Nordeste do Brasil - Único atol do Atlântico Sul Equatorial Ocidental. In: Schobbenhaus C, Campos DA, Queiroz ET, Winge $\mathrm{M}$ and Berbert-Born MLC (Eds), Sítios Geológicos e Paleontológicos do Brasil. $1^{\text {a }}$ ed., Brasilia: DNPM/ CPRM - Comissão Brasileira de Sítios Geológicos e Paleobiológicos (SIGEP), 2002, 1: 379-390.

Klippel S, Martins as, Olavo G, Costa PAS and Peres MB. 2005. Estimativas de desembarque da pesca de linha na costa central do Brasil (estados do Espírito Santo e Bahia) para um ano padrão (1997-2000). In: Costa PAS, Martins AS and Olavo G (Eds), Pesca e potenciais de exploração de recursos vivos na região central da Zona Econômica Exclusiva brasileira. Museu Nacional, Rio de Janeiro, p. 71-82.

LARA MR, SCHULl J, JONES DL AND ALLMAN R. 2009. Early life history stages of goliath grouper Epinephelus itajara (Pisces: Epinephelidae) from Ten Thousand Insulars, Florida. Endang Species Res 7: 221-228.

LeE W, Coroy J, Howell WH AND Koocher TD. 1995. Structure and evolution of teleost mitochondrial control regions. J Mol Evol 41: 54-66.

LUMPKIN R AND GARZOLI SL. 2005. Near-surface Circulation in the Tropical Atlantic Ocean. Deep-Sea Res Pt I 52: 495-518.

Maggio T, Andaloro F And Arculeo M. 2006. Genetic population structure of Epinephelus marginatus (Pisces, Serranidae) revealed by two molecular markers. Ital J Zool 73: 275-283.
MANTEL N. 1967. The detection of disease clustering and a generalized regression approach. Cancer Res 27: 209-220.

Martins AS, OlaVo G AND COSTA PAS. 2005. A pesca de linha de alto mar realizada por frotas sediadas no Espírito Santo, Brasil. In: Costa PAS et al. (Eds), Pesca e potenciais de exploração de recursos vivos na região central da Zona Econômica Exclusiva Brasileira. Rio de Janeiro: Museu Nacional, p. 35-55.

Martins AS, Olavo G AND Costa PAS. 2007. Padrões de distribuição e estrutura de comunidades de grandes peixes recifais a costa central do Brasil. In: Costa PAS, Martins AS and Olavo G (Eds), Biodiversidade da fauna marinha profunda na costa central brasileira. Rio de Janeiro: Museu Nacional, p. 45-62.

MENDES LF. 2006. História natural dos amborés e peixesmacaco (Actinopterygii, Blennioidei, Gobioidei) do Parque Nacional Marinho do Arquipélago de Fernando de Noronha, sob um enfoque comportamental. RBZool 23: 817-823.

MMA - MinistérIO DO MEIO AMBIENTE. 2004. Lista nacional das espécies de invertebrados aquáticos e peixes ameaçadas de extinção. Instrução Normativa $n^{0} 5$, de 21 de maio de 2004. Diário Oficial da União - Seção 1, 102: 136-142.

Mobley KB, Small CM, Jue NK And Jones AG. 2010. Population structure of the dusky pipefish (Syngnathus floridae) from the Atlantic and Gulf of Mexico, as revealed by mitochondrial DNA and microsatellite analyses. J Biogeogr 37: 1363-1377.

MORRIS AV. 2000. The threatened status of groupers (Epinephelinae). Biodivers Conserv 9: 919-942.

NELSON JS. 2006. Fishes of the world. $4^{\text {th }}$ ed., J Wiley \& Sons, Inc., New Jersey, 600 p.

RAY N, CURRAT M and EXCOFFIER L. 2003. Intra-deme molecular diversity in spatially expanding populations. Mol Biol Evol 20: 76-86.

Rivera MAJ, KelLey CD AND Roderick GK. 2004. Subtle population genetic structure in the Hawaiian Grouper, Epinephelus quernus (Serranidae) as revealed by mitochondrial DNA analyses. Biol J Linn Soc 81: 449468.

Rogers AR. 1995. Genetic evidence for a Pleistocene population expansion. Evolution 49: 608-615.

Rogers AR AND HARPENDING H. 1992. Population growth makes waves in the distribution of pairwise genetic differences. Mol Biol Evol 9: 552-569.

SAMBROOK J, FRITSCH EF and MANIATIS T. 1989. Molecular cloning: a laboratory manual. $2^{\text {nd }}$ ed., New York: Could Spring Harbor Laboratory Press, 1626 p.

SAntos S, HrbeK T, FARIAS IP, SchNeIDER H AND SAMPaio MI. 2006. Population genetic structuring of the king weakfish, Macrodon ancylodon (Sciaenidae), in Atlantic coastal waters of South America: deep genetic divergence without morphological change. Mol Ecol 15: 4361-73.

SAZIMA I, KRAJEWSKi J, BonALdo RM AND SAZIMA C. 2005. Wolf in a sheep's clothes: juvenile Coney Cephalopholis fulva as an aggressive mimic of the brown chromis (Chromis multilineata). Neotrop Ichthyol 3: 315-318. 
SCHNEIDER S and EXCOFFIER L. 1999. Estimation of past demographic parameters from the distribution of pairwise differences when the mutation rates vary among sites: application to human mitochondrial DNA. Genetics 152: 1079-1089.

Silva-OLIVEIRA GC, RÊGO PS, SChNEIDER H, SAMPAIO I AND VALLINOTO M. 2008. Genetic characterization of populations of the critically endangered Goliath grouper (Epinephelus itajara, Serranidae) from the Northern Brazilian coast through analyses of mtDNA. Genet Mol Biol 31: 988-994.

SLATKIN M AND HUDSON RH. 1991. Pairwise comparisons of mitochondrial DNA sequences in stable and exponentially Growing Populations. Genetics 129: 555-562.

SMITH CL. 1997. National Audubon Society field guide to tropical marine fishes of the Caribbean, the Gulf of Mexico, Florida, the Bahamas, and Bermuda. Alfred A. Knopf, Inc., New York, 720 p.

TAJIMA F. 1989. Statistical method for testing the neutral mutation hypothesis by DNA polymorphism. Genetics 123: 585-595.

Tamura K, Peterson D, Peterson N, Stecher G, Nei M AND KUMAR S. 2011. MEGA5: Molecular Evolutionary Genetics Analysis using Maximum Likelihood, Evolutionary Distance, and Maximum Parsimony Methods. Mol Biol Evol 28: 2731-2739.

Thompson JD, Gibson TJ, Plewniak F, Jeanmougin F and HIGGINS DG. 1997. The CLUSTAL X windows interface: flexible strategies for multiple sequence alignment aided by quality analysis tools. Nucleic Acids Res 24: 4876-4882.
Trott TM. 2006. Preliminary analysis of age, growth, and reproduction of Coney (Cephalopholis fulva) at Bermuda. Proc Gulf Caribb Fish Inst 57: 385-399.

VAsconcellos AV, Vianna P, Paiva PC, Schama R AND SOlÉ-CAVA A. 2008. Genetic and morphometric differences between yellowtail snapper (Ocyurus chrysurus, Lutjanidae) populations of the tropical West Atlantic. Genet Mol Biol 31(1): 308-316.

ViÑAs J, PÉREZ-SERRA A, VidAl O, BREMER JRA AND Pla C. 2010. Genetic differentiation between eastern and western Mediterranean swordfish revealed by phylogeographic analysis of the mitochondrial DNA control region. ICES J Mar Sci 67(6): 1222-1229.

WRIGHT S. 1978. Evolution and genetics of populations. Vol.2: The theory of gene frequencies. Londres: University of Chicago Press, $511 \mathrm{p}$.

XIA X and XIE Z. 2001. DAMBE: Data analysis in molecular biology and evolution. J Hered 92: 371-373.

ZATCOFF MS, BALL AO and SEDBERry GR. 2004. Population genetic analysis of red grouper, Epinephelus morio, and scamp, Mycteroperca phenax, from the southeastern U.S. Atlantic and Gulf of Mexico. Mar Biol 144: 769-777.

Zhang J, CAI Z and HuAng L. 2006. Population genetic structure of crimson snapper Lutjanus erythopterus in East Asia, revealed by analysis of the mitochondrial control region. ICES J Mar Sci 63: 693-704. 